Journal of Biotechnology 18(2): 341-348, 2020

\title{
EFFECT OF GAMMA IRRADIATION ON THE VIABILITY AND CELLULASE PRODUCTION OF SOME FILAMENTOUS FUNGI
}

\section{Tran Bang Diep ${ }^{\bowtie}$, Nguyen Thi Thom, Hoang Dang Sang, Tran Xuan An, Nguyen Van Binh, Tran Minh Quynh}

Hanoi Irradiation Centre, Minh Khai, Tu Liem, Hanoi

${ }^{\circledR}$ To whom correspondence should be addressed. E-mail: tranfbangdiepj@yahoo.com

Received: 13.3 .2020

Accepted: 04.6.2020

SUMMARY

The motivation of our research is to examine the mutagenic effect of gamma irradiation on cellulase secretion of some filamentous fungi. The spore suspensions of Aspergillus sp. TTG and Trichoderma sp. VTCC were irradiated at dose ranging 0-2500 Gy under gamma Cobalt-60 source at Ha Noi Irradiation Center. The result showed that the survival rate of fungi decreases with the increasing dose. The radiation dose required to kill $90 \%$ of the total number of fungal spores (D10) of these strains was about 400 Gy. The viability of Aspergillus sp. TTG and Trichoderma sp. VTCC at 500 Gy were $0.46 \%$ and $0.78 \%$, respectively, while the number of survival spore decreased by 6.5-7.5 Log unit at the dose of 2500 Gy. By screening in PDA medium with the addition of CMC (carboxymethyl cellulose) and Congo red as an indicator of cellulose degradation, hundreds of colonies with higher hydrolysis capacity's value (HC) compared to the initial strain were observed after irradiation. The colonies expressed the highest cellulose hydrolysis capacity with maximum HC value were obtained at dose range of 700-1500 Gy. It is important to notice the 5 potential mutants including 3 mutants of Aspergillus (TTG-700, TTG-1000 and TTG-1200) and 2 mutants of Trichoderma (VTCC-1000, VTCC-1500) demonstrated the higher CMCase secretion $(1.78-2.48$ times) compared to the wild types. After 5 generations, the enzyme productions of the mutants were fairly stable and there were no differences in growth rates and morphology of each generation. The result of this study is an evidence for using gamma irradiation to improve cellulase production in filamentous fungi.

Keywords: Aspergillus, cellulase, gamma irradiation, mutant, Trichoderma, spore

\section{INTRODUCTION}

Cellulose, a $\beta$ (1-4) - linked glucose polymer, is considered to be the most abundant renewable carbon resource in the world (Gardner, Blackwell, 1974; Jarvis, 2003). By using cellulase enzyme system, cellulose can be converted to glucose, which is a multi-utility product, in a cheap and biologically propitious process (Gupta et al., 2003). The aerobic decomposition of cellulose is mainly carried out by filamentous fungi. The cellulase complex secreted by these microogranisms consists of three classes of soluble extracellulase: a 1-4- $\beta$ endoglucanase, a 1-4- $\beta$-exoglucanase and $\beta$ glucosidase, which act synergistically on both the amorphous and crystalline regions of cellulose during the conversion to glucose (Henrissat, 1994; Wang et al., 2011).

The filamentous fungi Aspergillus spp. and Trichoderma spp. are present in almost all types of soil and many natural surroundings. They have been studied extensively because of their 
low-cost culturing and producing efficient cellulase for cellulose degradation. The biomass of these fungi can easily be separated from the culture filtrate, which contains the secreted extracellular enzyme. Thanks to this feature, fungi gained an advantage over the bacteria in the process of industrial cellulase production (Miklaszewska et al., 2016).

Gamma rays are the most energetic forms of ionizing radiation and characterized by their short wavelength, which enables their deep penetration into the matter. Gamma irradiation causes mutations through single-or doublestrand breakage of DNA resulting from deletion or structural change, DNA-protein cross links, oxidation, bases, and basic sites (Hoe et al., 2016).

To improve the cellulase production of Aspergillus spp. and Trichoderma spp., there have been dedicated works focusing on the mutation of these strains by gamma rays. $\mathrm{Vu}$ and orthers (2009) showed that Aspergillus sp. was further improved for cellulase production by sequential treatments by two repeated rounds of gamma irrradiation of Co-60 (Vu et al., 2009). Gamma irradiation at $2 \mathrm{kGy}$ of Aspergillus niger also enhances the production of carboxymethyl cellulase (CMCase) and filter paper cellulase (Fpase) (Mostafa, 2014). Shahbazi and orthers (2014) reported that Trichoderma reesei irradiated at 250 Gy of gamma ray produced a maximum amount of cellulase compared to wild type strains and UV-irradiated mutants. Enzyme assay verified that the gamma irradiated mutants shows approximately 1.21-1.99 fold increases in the activity of each component enzyme of cellulase system in shake flask culture (Shahbazi et al., 2014). The mutants of Trichoderma reesei irradiated at $2 \mathrm{kGy}$ of gamma ray secreted 1.8 times as much cellulase as the untreated fungi (Masao et al., 1987).

The purpose of this study is to investigate the effects of gamma ray on the viability of two strains of Aspergillus sp. TTG and Trichoderma sp. VTCC, and using gamma irradiation for enhancing cellulase production of these strains of filamentous fungi.

\section{MATERIALS AND METHODS}

\section{Strains and media}

Two rather high cellulase-producing filamentous fungi, Aspergillus sp. TTG and Trichoderma sp. VTCC, were purchased from Institute of Microbiology and Biotechnology, Vietnam National University, Ha Noi.

Potato destrose agar (PDA) media, 3,5dinitrosalicylic (DNS) and other chemicals at analytical grade were purchased from Merck, Gemany. Carborxyl methyl cellulose (CMC), Congo red, streptomycin was bought from Sigma.

The medium for shaking flask culture contained: $\quad \mathrm{CMC} 2 \mathrm{~g} / \mathrm{L}, \quad \mathrm{KH}_{2} \mathrm{PO}_{4} 4 \mathrm{~g} / \mathrm{L}$, $\left(\mathrm{NH}_{4}\right)_{2} \mathrm{SO}_{4} 13.6 \mathrm{~g} / \mathrm{L}, \mathrm{CaCl}_{2} 0.8 \mathrm{~g} / \mathrm{L}, \mathrm{MgSO}_{4} 0.6$ $\mathrm{g} / \mathrm{L}$, pepton $0.1 \mathrm{~g} / \mathrm{L}$, yeast extract $0.1 \mathrm{~g} / \mathrm{L}$, $\mathrm{FeSO}_{4} \cdot \mathrm{H}_{2} \mathrm{O} 1 \mathrm{mg} / \mathrm{L}, \mathrm{MnSO}_{4} .2 \mathrm{H}_{2} \mathrm{O} 0.32 \mathrm{mg} / \mathrm{L}$, $\mathrm{ZnSO}_{4} .7 \mathrm{H}_{2} \mathrm{O} 0.28 \mathrm{mg} / \mathrm{L}, \mathrm{CoCl}_{2} .6 \mathrm{H}_{2} \mathrm{O} 0.4 \mathrm{mg} / \mathrm{L}$, $\mathrm{CuSO}_{4} .5 \mathrm{H}_{2} \mathrm{O} 0.25 \mathrm{mg} / \mathrm{L}$.

\section{Preservation of microorganisms}

The wild types of Aspergillus sp. TTG and Trichoderma sp. VTCC were inoculated on a slant of PDA and kept in an incubator at $28^{\circ} \mathrm{C}$ for 72 hours. Fungi were then stored at $4^{\circ} \mathrm{C}$, up to maximum 30 days before sub-culturing.

\section{Preparation of spore suspension}

Spore suspensions were prepared using the method described by Darabzadeh and others (2018) (Darabzadeh et al., 2018). The fungi were inoculated on PDA plates and incubated at $28^{\circ} \mathrm{C}$ for 1 week. The spore suspension of fungi was prepared by adding a sterile saline solution $(\mathrm{NaCl}$ $0.9 \%$ ) to PDA plates and scrapped well. In the next step, the suspensions were distributed in the test tubes and shaken to achieve homogeneity. The final concentration of spore was adjusted to around $10^{8}-10^{9} \mathrm{CFU} / \mathrm{mL}$. 


\section{Irradiation}

The tubes of spore suspension were irradiated in duplicate at the same dose rate with the radiation doses ranging from 100 to $2500 \mathrm{~Gy}$ under gamma ray ${ }^{60} \mathrm{Co}$ source. Actual absorbed doses were measured by Gammachrome YR dosimeters.

\section{Survival assay}

The ten-fold serial dilutions of the unirradiated and irradiated spore suspensions were prepared in saline solution, then $0.1 \mathrm{~mL}$ of the appropriate diluted suspensions were inoculated on PDA plates ( 3 plates for 1dilution), incubated at $28^{\circ} \mathrm{C}$ for 72 hours for determining the effects of gamma radiation on fungal survival. The number of survival spores (Mi) in $1 \mathrm{~mL}$ of the suspension were calculated by the formula:

\section{$\operatorname{Mi}(\mathbf{C F U} / \mathrm{mL})=\mathrm{Ai} \times \mathrm{Di} / \mathrm{V}$}

Where $\mathrm{Ai}$ is the average number of colonies for plate; $\mathrm{Di}$ is the appropriate dilution and $\mathrm{V}$ is the volume of spore suspension inoculated in plate $(\mathrm{mL})$.

\section{Screening potential high cellulase mutants}

The cellulose-degradation ability of colonies of two fungal strains were determined semiquantitatively by the diffusion method on PDA agar plate containing 1\% CMC substrate, $0.02 \%$ Congo red as an indicator and streptomycin (50 mg/L) (Miklaszewska et al., 2016).

After irradiation, spore suspensions at different doses were immediately diluted and placed onto prepared PDA/CMC/Congo red medium. The plates were incubated at $28^{\circ} \mathrm{C}$ for 2 days, followed by a 5 -day incubation at $37^{\circ} \mathrm{C}$. Hypercellulolytic mutants were selected on the basis of the hydrolysis capacity (HC). The HC was calculated as the ratio of the diameter of cellulose hydrolysis zone marked by Congo red to the diameter of colony growing on a given cellulose medium.

Colonies with a $\mathrm{HC}$ value greater than $10 \%$ compared to $\mathrm{HC}$ value of wild strain were considered as the potential mutants producing high cellulase.

\section{Enzymatic assay}

For this purpose, 2 wild types of fungal strains and the irradiated colonies with the highest $\mathrm{HC}$ value selected from the prior stage were cultivated separately onto the shake flask culture. After the incubation at $28^{\circ} \mathrm{C}$ for 7 days, the cultures were centrifuged at $10,000 \mathrm{rpm}$ for $5 \mathrm{~min}$ at $4^{\circ} \mathrm{C}$. Supernatants were collected as crude enzyme for enzymatic assay (Miklaszewska et al., 2016; Shahbazi et al., 2014).

Endoglucanase activity (CMCase) was determined using the 3,5-dinitrosalicylic acid (DNS) method. The reaction systems were prepared as follows: $100 \mu \mathrm{L}$ of crude enzyme (appropriately diluted) mixed with $200 \mu \mathrm{L}$ of $1 \%$ $(\mathrm{w} / \mathrm{v}) \mathrm{CMC}$. The buffer used for dissolving or resuspending the substrates was $50 \mathrm{mM}$ sodium citrate buffer ( $\mathrm{pH} 4.8$ ). The mixtures were kept at $50^{\circ} \mathrm{C}$ for $20 \mathrm{~min}$. The reaction was then stopped by adding $0.6 \mathrm{~mL}$ of DNS reagent. The mixtures were heated in boiling water for $5 \mathrm{~min}$ for color development. Absorbance was read by spectrophotometer at $540 \mathrm{~nm}$ (2400 Shimazu UV-Vis). One unit (U) of the enzyme activity was defined as the amount of enzyme that released $1 \mu \mathrm{mol}$ of reducing sugars equivalent to glucose per minute during the reaction.

\section{RESULTS AND DISSCUSSION}

\section{Effect of gamma radiation on the growth of filamentous fungi}

The effect of gamma irradiation on the growth of two filamentous fungi strains was determined through their viability in irradiated spore suspension at dose ranging from 100 to 2500 Gy. Figure 1 expressed the correlation between logarithm of survival spore in CFU/mL with radiation dose. The results showed that the fungal viability was considerably affected by gamma radiation, and the survival spore was decreased with the increase of radiation dose. At 
the dose range of 100-1200 Gy, the number of colonies quickly reduced, while these amounts were less variable at doses higher than $1200 \mathrm{~Gy}$. It is obvious that the radiation effect does not show significant differences between Aspergillus sp. TTG and Trichoderma sp.VTTC.

Assessing the impact of gamma radiation on A. niger, Ottenheim and orthers (2015) reported that the D10 (the radiation dose required to kill $90 \%$ of the total number of microogranisms) was $400 \mathrm{~Gy}$ (Ottenheim et al., 2015) and this value is similar to that estimated for other strains of Aspergillus reported in various literature (Blank, Corrigan, 1995; Saleh et al., 1988). In the study on the viability of Trichoderma viride with gamma irradiation, Baharvand and orthers (2014) indicated that the number of survival spores was $9.7 \%$ at 400 Gy and no germination was observed at dose of $450 \mathrm{~Gy}$ (Baharvad et al., 2014). Laura and orthers (2014) reported that D10 of Trichoderma viride was about 450-500 Gy (Laura et al., 2014). The D10 of all two fungal strains in our study was also about 400 Gy. The viability of Aspergillus sp. TTG and Trichoderma sp. VTCC at 500 Gy were $0.46 \%$ and $0.78 \%$, respectively, while the number of survival spore decreased by 6.5-7.5 Log unit at the dose of $2500 \mathrm{~Gy}$. These differences could be attributed to several factors that affect on the survival of irradiated spore such as temperature, density of spore suspension, chemical composition of the medium as well as physiological condition of individual cells and their potential for repairing.

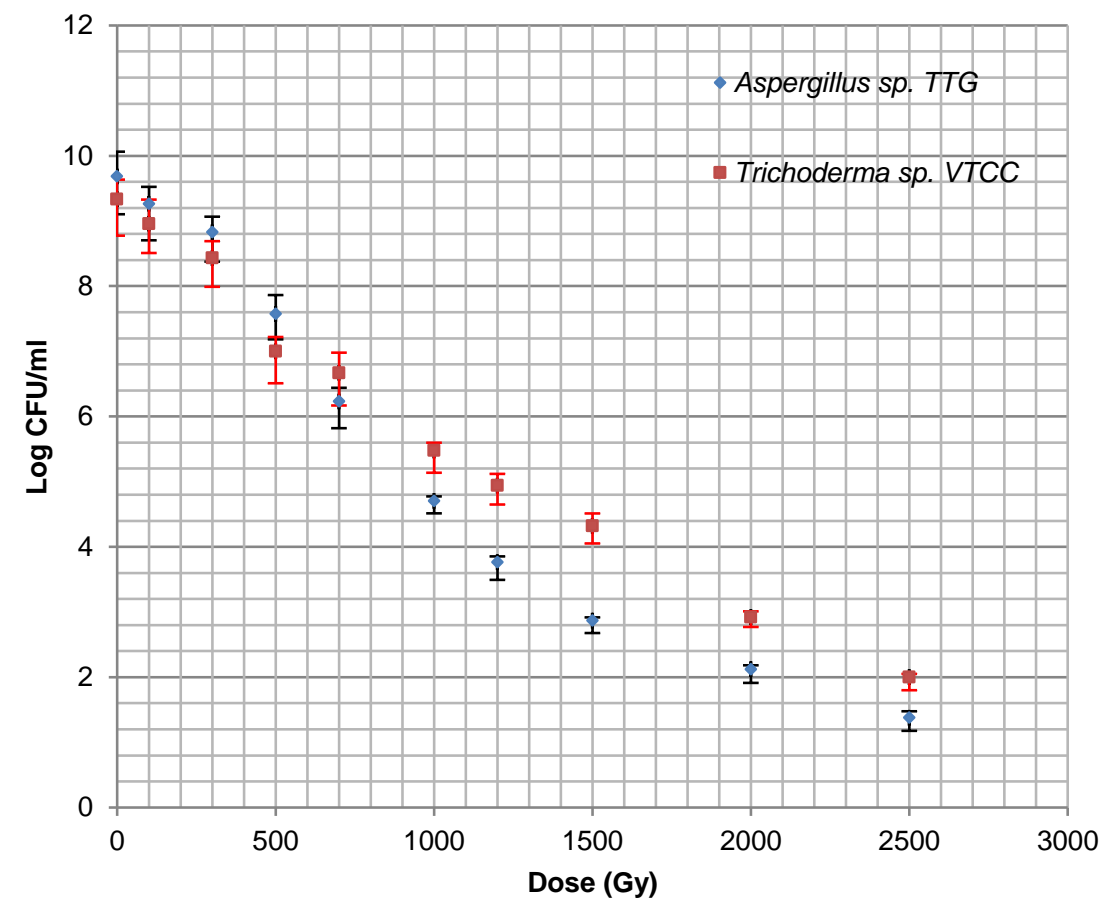

Figure 1. Effects of gamma irradiation on the viability of Aspergillus sp. TTG. and Trichoderma sp. VTCC.

Enhancement of cellulase production by gamma irradiation treatment

After irradiation, colonies of two fungal strains with $\mathrm{HC}$ value of $10 \%$ greater than $\mathrm{HC}$ of wild type strains are considered the potential mutants capable of high cellulase producing. The results showed that the colonies with clear zone of 
CMC resolution appeared at all irradiation doses on the screening media. However, the number of colonies with a high $\mathrm{HC}$ value were different for each dose (Figure 2).

Table 1 shows that the dose range of 7001500 Gy enabled to create the highest number

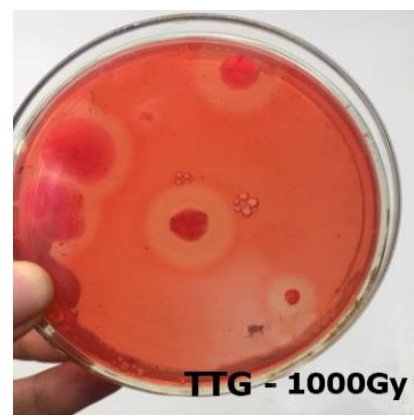

of colonies having high $\mathrm{HC}$ values, compared to other treatment doses. It is clearly shown in the average HC value of both Aspergillus sp. TTG and Trichoderma sp. VTCC. Furthermore, the colonies expressed the highest cellulose hydrolysis capacity with maximum $\mathrm{HC}$ value were also obtained at this irradiation dose range.

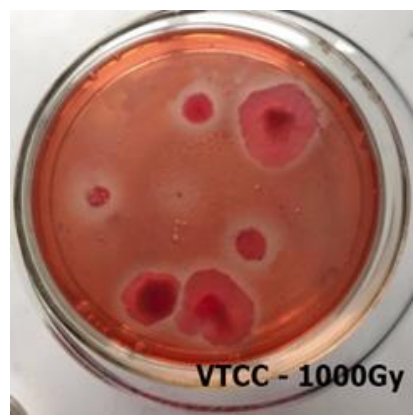

Figure 2. The colonies with clear zone of $C M C$ resolution appeared at dose of 1000 Gy on PDA/CMC/Congored screening media (A-The colonies of Aspergillus sp. TTG and B-The colonies of Trichoderma sp.VTCC)

Table 1. The cellulose hydrolysis capacity of two fungal strains irradiated at different doses.

\begin{tabular}{lll}
\hline Dose (Gy) & \multicolumn{2}{c}{ Average HC value } \\
\cline { 2 - 3 } & Aspergillus sp. TTG & Trichoderma sp. VTCC \\
\hline Wild type & 1.82 & 1.74 \\
300 & $2.01 \pm 0.06$ & $1.95 \pm 0.10$ \\
500 & $2.06 \pm 0.02$ & $1.94 \pm 0.05$ \\
$\mathbf{7 0 0}$ & $\mathbf{2 . 1 7} \pm \mathbf{0 . 0 8}$ & $\mathbf{2 . 0 5} \pm \mathbf{0 . 0 9}$ \\
$\mathbf{1 0 0 0}$ & $\mathbf{2 . 4 3} \pm \mathbf{0 . 1 2}$ & $\mathbf{2 . 2 1} \pm \mathbf{0 . 1 1}$ \\
$\mathbf{1 2 0 0}$ & $\mathbf{2 . 3 9} \pm \mathbf{0 . 1 0}$ & $\mathbf{2 . 1 7} \pm \mathbf{0 . 0 9}$ \\
$\mathbf{1 5 0 0}$ & $\mathbf{2 . 3 2} \pm \mathbf{0 . 0 4}$ & $\mathbf{2 . 0 6} \pm \mathbf{0 . 1 4}$ \\
2000 & $2.11 \pm 0.09$ & $2.01 \pm 0.07$ \\
2500 & $2.07 \pm 0.10$ & $1.95 \pm 0.02$ \\
\hline
\end{tabular}

\section{Cellulase activity}

Five potential mutants including 3 mutants of Aspergillus sp. TTG (TTG-700, TTG-1000 and TTG-1200) and 2 mutants of Trichoderma sp. VTCC (VTCC-1000, VTCC-1500) possessing the highest $\mathrm{HC}$ value (HC>2.0 for Aspergillus sp. and $\mathrm{HC}>1,9$ for Trichoderma sp.) and enzyme activities were selected from hundreds of irradiated colonies. The clear zones of CMC and
CMCase activity of some potential mutants were shown in Figure 3 and Table 2.

Several studies using radiation treatment to create high cellulase-producing mutations in Aspergillus spp. and Trichoderma spp. also showed the effectiveness of gamma ray ( Vu et al., 2009; Mostafa, 2014; Shahbazi et al., 2014; Masao et al., 1987). In this study, some potential mutants were capable of higher CMCase secretion 
(2.25-2.37 times for Aspergillus and 1.78-2.48 times for Trichoderma), compared to the wild type strains were screened at the dose range of 700-1500 Gy.

The stability of these mutants for cellulase production was determined by the successive

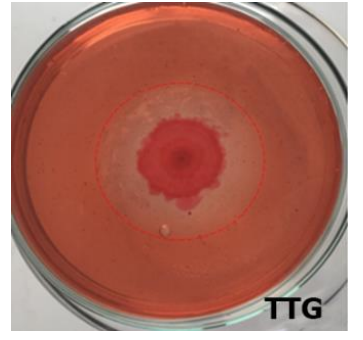

Aspergillus sp. TTG

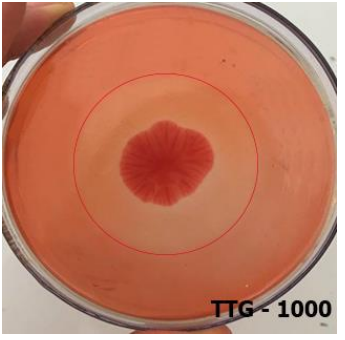

TTG-1000

subculturing on PDA plates for over 5 months. After 5 generations, CMCase production remained fairly stable with variation coefficients not exceeding 5\% (data not shown). In addition, there are no differences in growth rates and morphology of each generation.

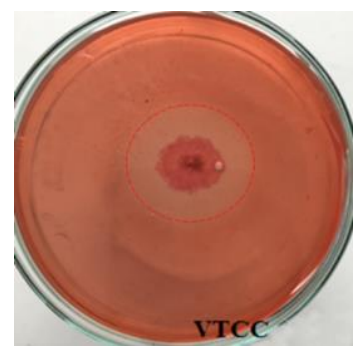

Trichoderma sp. VTCC

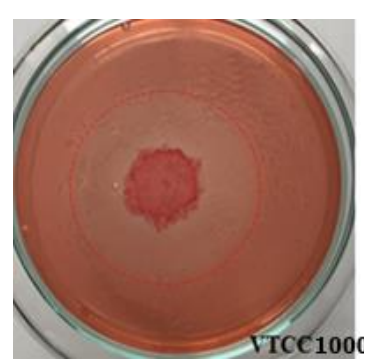

VTCC-1000

Figure 3. The clear zones of $\mathrm{CMC}$ resolution of wild type strains and potential mutants incubated at $28^{\circ} \mathrm{C}$ for 2 days, followed by a 5 -day incubation at $37^{\circ} \mathrm{C}$

Table 2. The activities of CMCase produced by two wild type strains and 5 potential mutants.

\begin{tabular}{llll}
\hline Fungal strain & CMCase activity $(\mathbf{U} / \mathbf{m l})$ & $\begin{array}{l}\text { Comparison to the wild } \\
\text { type strain (times) }\end{array}$ \\
\hline & Aspergillus sp. TTG & $1.324 \pm 0.04$ & - \\
Aspergillus spp. & TTG-700 & $2.979 \pm 0.12$ & 2.25 \\
& TTG-1000 & $3.137 \pm 0.05$ & 2.37 \\
& TTG-1200 & $3.071 \pm 0.11$ & 2.32 \\
\hline \multirow{3}{*}{ Trichoderma spp. } & Trichoderma sp. VTCC & $1.107 \pm 0.04$ & - \\
& VTCC-1000 & $2.753 \pm 0.09$ & 2.48 \\
& VTCC-1500 & $1.978 \pm 0.07$ & 1.78 \\
\hline
\end{tabular}

\section{CONCLUSION}

The viability of Aspergillus sp. TTG and Trichoderma sp. VTCC was quickly reduced by gamma irradiation. The D10 of all two fungal strains was about $400 \mathrm{~Gy}$ and the number of survival spore decreased by 6.5-7.5 Log unit at the dose of $2500 \mathrm{~Gy}$. The 5 potential mutants possessing the highest CMCase activity (1.782.48 times higher compared to wild type) were selected from hundreds of irradiated fungal colonies. The result of the present study is an evidence for using gamma irradiation to improve cellulase production in filamentous fungi.
Acknowledgments: This study was financially supported by the Ministry of Science and Technology, Vietnam under the project of ĐTCB.01/18/TTCX.

\section{REFERENCES}

Baharvad A, Shahbazi S, Afsharmanesh H, Ebrahimi MA, Askari H (2014) Investigation of gamma irradiation on morphological characteristics and antagonist potential of Trichoderma viride against M.phaseolina. Int J Farm \& Alli Sci: 1157-1164.

Blank G, Corrigan D (1995) Comparision of resistance of fungal spore to gamma and electron 
beam radiation. Int. J. Food Microbiol 26: 269-277.

Darabzadeh N, Hamidi-Esfahani Z, Hejazi P (2018) Improvement of cellulase production and its characteristics by inducing mutation on Trichoderma reesei 2414 under solid state fermentation on rice byproducts. Appl Food Biotechnol 5 (1): 11-18.

Gardner KH, Blackwell J (1974) The structure of native cellulose. Biopolymers 13: 1975-2001.

Gupta P, Samant K, Sahu A (2012) Isolation of cellulose- degrading bacteria and determination of their cellulolytic potential. Int J Microbiol 6: 1-5.

Henrissat B (1994) Cellulases and their interaction with cellulose. Cellulose 1: 169-196.

Hoe PCK, Rahim KA, Saud HM (2016) A review on microbial mutagenesis through gamma irradiation for agricultural applications. Jurnal Sains Nuklear Malaysia 28(2): 20-29.

Jarvis M (2003) Cellulose stacks up. Nature, 426 (6967): 611-612.

Laura T, Florina LZ, Mioara A, Mihaela E, Mihai C, Alexandru A, Mihalis C, Ovidui I, Rodica IS (2014) Radioresistance of biodegradation fungi and its importance in establishing the decontamination dose. ICAMS 2014-5th International Conference on Advanced Materials and Systems.

Masao T, Noboru K, Isao K (1987) Effects of gammaray irradiation on cellulase secretion of Trichoderma reesei. Ferment Technol 65 (6): 703-705.
Miklaszewska B, Macko D, Kłosowski G, Mikulski D (2016) Application of semi-quantitative and quantitative methods for the selection of cellulolytic filamentous fungi isolated from pulp mill materials. Bio Technologia 97 (3): 169-178.

Mostafa AA (2014) Effect of gamma irradiation on Aspergillus niger DNA and production of cellulase enzymes. J American Sci 10(5):152-160.

Ottenheim C, Werner KA, Zimmermann W, Wu JC (2015) Improved endoxylanase production and colony morphology of Aspergillus niger DSM 26641 by $\gamma$-ray induced mutagenesis. Biochem Engin J 94: 9-14.

Saleh YG, Mayo MS, Ahearn DG (1988) Resistance of some common fungito gamma irradiation. Appl Environ Microbiol 54(8): 2134-2135.

Shahbazi S, Ispareh K, Karimi M, Askari H, Ebrahimi M A (2014) Gamma and UV radiation induced mutagenesis in Trichoderma reesei to enhance cellulases enzyme activity. Intl J Farm \& Alli Sci 3(5): 543-554.

Vu VH, Pham TA, Kim (2009) Fungal strain improvement for cellulase production using repeated and sequential mutagenesis. Mycobiol 37(4): 267271.

Wang FXJ, Chen S, Qiu W, Yu Z, Zhao H, Xing X, Li $H$ (2011) Strain improvement for enhanced production of cellulase in Trichoderma viride. Appl Biochem Microbiol 47 (1): 53-58.

\section{ẢNH HƯởNG CỦA CHIẾU XẠ GAMMA TỚI TỶ LÊ SỐNG SÓT VÀ KHẢ NĂNG SINH CELLULASE CỦA MộT SỐ CHỦNG NẤM Sợi}

\section{Trần Băng Diệp, Nguyễn Thị Thơm, Hoàng Đăng Sáng, Trần Xuân An, Nguyễn Văn Bính, Trần Minh Quỳnh}

Trung tâm chiếu xạ Hà Nội, Minh Khai, Bắc Tù̀ Liêm, Hà Nội

\section{TÓM TẮT}

Mục đích của nghiên cứu là bước đầu khảo sát tác dụng gây đột biến sinh cellulase cao ở một số chủng nấm sợi bởi bức xạ gamma. Dung dịch bào tử của Aspergillus sp. TTG và Trichoderma sp. VTCC được xử lý chiếu xạ ở dải liều 0-2500 Gy trên nguồn gamma Co-60 tại Trung tâm Chiếu xạ Hà Nội. Kểt quả cho thấy, tỷ lệ bào tử nấm sống sót giảm theo liều chiếu. Liều gây chết $90 \%$ số lượng bào tử nấm (D10) của cả hai chủng này đều khoảng $400 \mathrm{~Gy}$. Số lượng bào tử sống sót của Aspergillus sp. TTG và Trichoderma sp. VTCC ở liều 500 Gy lần lượt là $0,46 \%$ và $0,78 \%$ và giảm tới $6,5-7,5$ đơn vị Log so với đối chứng ở liều $2500 \mathrm{~Gy}$. Sau chiếu xạ, tiến hành sàng lọc trên môi trường PDA có bổ sung CMC (carboxymethyl cellulose) với chỉ thị Congo đỏ đã thu được hàng trăm khuẩn lạc 
có khả năng thủy phân cellulose $(\mathrm{HC})$ lớn hơn chủng ban đầu. Trong đó, các khuẩn lạc thể hiện khả năng thủy phân cellulose cao nhất với giá trị HC tối đa thu được ở khoảng liều 700-1500 Gy. Đặc biệt, 5 thể đột biến tiềm năng bao gồm 3 thể đột biến từ Aspergillus (TTG-700, TTG-1000 và TTG1200 ) và 2 thể đột biến từ Trichoderma (VTCC-1000 và VTCC-1500) có hoạt tính CMCase tăng 1,78-2,48 lần so với chủng gốc. Khả năng sinh CMCase của các thể đột biến được duy trì ổn định ít nhất sau 5 thế hệ liên tiếp, đồng thời không có sự khác biệt về tốc độ sinh trưởng và hình thái ở mỗi thế hệ. Kết quả của nghiên cứu là bằng chứng cho thấy khả năng ứng dụng phương pháp chiếu xạ gamma để tăng cường sản xuất cellulase ở các chủng nấm sợi.

Từ khóa: Aspergillus, bào tủ, cellulase, chiếu xa gamma, đột biến, Trichoderma 